\title{
Oil money takes US academy into uncharted waters
}

\section{Venerable government adviser will fund grants with half-billion-dollar windfall.}

\section{BY HELEN SHEN}

$\mathrm{B}$ reaking its 150-year-old tradition as a prominent scientific advisory group for the US government, the National Academy of Sciences (NAS) is quietly preparing to launch a major research-grant programme. The programme will be part of a US $\$ 500$-million, 30-year initiative to study environmental science and human health in the wake of the 2010 oil spill in the Gulf of Mexico.

The academy, based in Washington DC, was awarded the funds under two legal settlements stemming from the Deepwater Horizon oil spill, which spewed more than 600 million litres of oil into the gulf. With the awards, the NAS joins the small club of non-governmental organizations poised to support much of the research in the gulf in coming years (see 'Oil money everywhere'). But the timetable for the spending, and the research areas to be supported, are uncertain. "We're trying to get our plans in place," says NAS president Ralph Cicerone. "We're not ready yet."

Over the next five years, British oil-and-gas giant BP will give the NAS \$350 million, and Swiss oil-rig contractor Transocean will add $\$ 150$ million - money that officials at the NAS say they were surprised to receive. The US Department of Justice, which organized the settlements, said in a statement that the NAS was chosen for its institutional independence. The first $\$ 5$ million is scheduled to arrive by 29 April and larger instalments are slated for coming years. Cicerone says that "a fair amount" of the money will support external research projects - an unusual role for the institution, which mostly prepares scientific reports for government agencies.

Some scientists worry that the academy lacks experience in competitive peer review and grant oversight. "I don't know what entity within the national academy would be involved," says James Carr, a fish biologist at Texas Tech University in Lubbock. "We haven't heard anything about what the mechanism is going to be."

Cicerone acknowledges that setting up the research programme will lead the NAS into new territory, but points to the academy's experience in convening experts to conduct and peer review reports. "There's really nothing

\section{$\rightarrow$ NATURE.COM} For more on the Deepwater Horizon spill, see: nature.com/oilspill

\begin{tabular}{|c|c|c|c|c|}
\hline \multicolumn{5}{|c|}{$\begin{array}{l}\text { OIL MONEY EVERYWHERE } \\
\text { Penalties and reparations from the } 2010 \text { Deepwater Horizon spill have enriched three non-governmental } \\
\text { organizations that support research. }\end{array}$} \\
\hline $\begin{array}{l}\text { Organization } \\
\text { (founding date) }\end{array}$ & Source & Amount & Objectives & $\begin{array}{l}\text { Funding } \\
\text { start/end }\end{array}$ \\
\hline GoMRI (2010) & BP donation & $\begin{array}{l}\text { US } \$ 500 \\
\text { million }\end{array}$ & $\begin{array}{l}\text { Oil dispersion and degradation studies; } \\
\text { ecological and health effects }\end{array}$ & 2010-20 \\
\hline NFWF (1984) & $\begin{array}{l}\text { BP and Transocean } \\
\text { plea agreements }\end{array}$ & $\begin{array}{l}\text { US } \$ 2.55 \\
\text { billion }\end{array}$ & $\begin{array}{l}\text { Restoration and risk-reduction projects; } \\
\text { construction of barrier islands }\end{array}$ & $\begin{array}{l}\text { 2013-until } \\
\text { depleted }\end{array}$ \\
\hline NAS (1863) & $\begin{array}{l}\text { BP and Transocean } \\
\text { plea agreements }\end{array}$ & $\begin{array}{l}\text { US } \$ 500 \\
\text { million }\end{array}$ & $\begin{array}{l}\text { Environmental protection and } \\
\text { human health studies; education and } \\
\text { environmental monitoring }\end{array}$ & 2013-43 \\
\hline
\end{tabular}

GoMRI, Gulf of Mexico Research Initiative; NFWF, National Fish and Wildlife Foundation; NAS, National Academy of Sciences

so different there," he says. The academy is also trying to learn from organizations that already have a head start on distributing grants in the area, Cicerone says.

The National Fish and Wildlife Foundation in Washington DC, which received $\$ 2.55$ billion from BP and Transocean under the plea agreements, is focusing on recovery projects - including barrier-island construction off the Louisiana coast and river-diversion projects along the Mississippi River. By contrast, the Gulf of Mexico Research Initiative

\section{"Once the cheques start showing up, there will be an enormous amount of pressure to spend."} (GoMRI) - a \$500-million, 10-year competitive grants programme established by BP in the months following the oil spill - supports basic science. Modelled after the National Science Foundation (NSF), GoMRI has funded studies on the distribution and degradation of oil and chemical dispersants, as well as their ecological impacts. Rita Colwell, the chair of the GoMRI research board and a former director of the NSF, says that her organization has been holding discussions with the NAS. "We're willing to share what we've learned."

The NAS has yet to decide how it will balance its portfolio between basic and applied research, ecological and human-health studies, and short-term and long-term projects. Maureen Lichtveld, an environmental-health researcher at Tulane University in New Orleans, Louisiana, would like to see more funding for human health, which she says has received less support from GoMRI than ecological research. Lichtveld hopes that NAS funds will enable her to expand her studies of women and children who have eaten seafood from the Gulf. Samantha Joye, a biogeochemist at the University of Georgia in Athens who studies sea-floor microbes and invertebrates, views the academy's 30-year mission as an opportunity to support extended - and continuous - ecological monitoring projects.

Cicerone says that the grants programme will complement the other funding sources. In January, NAS representatives spoke to Joye and several other scientists at a GoMRI-sponsored conference in New Orleans to identify research areas that have lacked support.

Steven Murawski, a fisheries biologist at the University of South Florida in St Petersburg, says that there is no shortage of things to do. He says that the academy faces a daunting task - not just in identifying priorities but also in disbursing funds quickly, while the effects of the oil spill linger. "Once the cheques start showing up, there will be an enormous amount of pressure to spend."

\section{CORRECTIONS}

The map in the story 'Quake fears rise at Japan's reactors' (Nature 494, 14-15; 2013) wrongly suggested that only a single reactor, rather than the whole plant, is under inspection at $\mathrm{Oi}$.

The News story 'Company offers portable peer review' (Nature 494, 161; 2013) wrongly stated that the European Molecular Biology Organization's open peer review was not anonymous - the reviews are made public but are anonymized. 